\title{
Efektivitas pendekatan Science Technology Community (STM) untuk meningkatkan prestasi belajar ilmu pengetahuan sosial siswa sekolah dasar
}

\author{
Desrinelti Desrinelti ${ }^{\left.1^{*}\right)}$, Firman Firman ${ }^{2}$, Desyandri Desyandri ${ }^{3}$ \\ ${ }^{123}$ Universitas Negeri Padang
}

\begin{tabular}{l} 
Article Info \\
\hline Article history: \\
Received Jan $29^{\text {th }}, 2021$ \\
Revised Feb $11^{\text {th }}, 2021$ \\
Accepted Feb $19^{\text {th }}, 2021$ \\
\hline
\end{tabular}

\section{Keyword:}

Sains teknologi masyarakat Hasil belajar

Sekolah dasar

\begin{abstract}
ABSTRAK
Penelitian ini didasarkan pada realita di sekolah dasar yaitu hasil belajar peserta didik dan proses belajarnya belum memadai seperti diinginkan karena pendekatan yang digunakan guru dinilai masih kurang efektif. Pendekatan yang digunakan untuk pembelajaran IPS pada riset ini adalah penelitian eksperimen. Tujuan dari riset ini agar prestasi belajar siswa kelas V SDN 12 Parambahan pada pembelajaran IPS dapat ditingkatkan. Jumlah peserta didik kelas V sebanyak 19 orang dengan laki-laki 10 dan perempuan orang. Dilihat dari hasil penelitian ini ada peningkatan dari etiap siklusnya.Siklus pertama diperoleh nilai 69 sedangkan pada siklus kedua 80. Jadi dapat disimpulkan dengan pendekatan STM yang digunakan prestasi belajar peserta didik pada pelajaran IPS meningkat. Yang membedakan penelitian ini adalah kelebihan pendekatan STM ini mudah dan terampil mengidentifikasi penyebab atau dampak penggunaan teknologi, siswa dapat melihat bahwa sains adalah alat yang mampu memecahkan masalah.
\end{abstract}

(C) 2021 The Authors. Published by IICET.

This is an open access article under the CC BY-NC-SA license

(https://creativecommons.org/licenses/by-nc-sa/4.0

\section{Corresponding Author:}

Desrinelti Desrinelti,

Universitas Negeri Padang

Email: desrinelti@gmail.com

\section{Introduction}

Sekarang ini pada zaman abad-21 teknologi semakin maju dan berkembang baik di bidang pendidikan maupun di bidang lain. Hal ini menyebabkan teknologi semakin pesat masuk ke dunia pendidikan sehingga menimbulkan dampak positif dan negaif. Dampak positifnya teknologi bisa memberikan manfaat bagi kita dalam mencari informasi yang ada di luar negeri dengan cepat serta mudah melakukan pekerjaan dengan menggunakan alat-alat teknologi yang diciptakan. Dampak negatifnya apabila kurangnya pengetahuan yang kita miliki untuk menggunakan teknologi tersebut terutama di bidang sains serta menggunakan teknologi untuk hal-hal yang bersifat negatif. Pendidikan sains akan menghasilkan manusia yang berkualitas contohnya pada pelajaran IPS yang dapat menerapakannya pada lingkungan masyarakat, berpikir cerdas, bermanfaat, analitis dan berinisitif dalam memahami fakta atau fenomena sosial yang meningkat di lngkungan sekitar akibat peengaruh era globalisasi kemajuan zaman yang berkembang. Syaharuddin, Mutiani (2020) menyimpulkan bahwa pembelajaran IPS sebagai pembelajaran yang mengintegrasikan konsep terpilih dari berbagai ilmu-ilmu sosial dan humaniora. Selanjutnya menurut S Jauhar (2018) "Pengembangan bahan ajar sains dengan pendekatan STM membentuk proses pembelajaran yang menekankan pada penguasaan konsep sains dan menekankan pada peran IPTEK dalam berbagai masyarakat. Hidup dan menumbuhkan rasa tanggung jawab sosial terhadap dampak ilmu pengetahuan dan teknologi di masyarakat. Melalui pendekatan 
Community Science, dapat dikembangkan 6 ranah keilmuan yaitu aspek konsep, proses, kreativitas, sikap, aplikasi, dan keterkaitan.".

Dari fakta yang penulis lihat saat melakukan supervisi akademik pada kelas V SDN 12 Parambahan Kecamatan Lima Kaum Kabupaten Tanah Datar pembelajaran IPS bagi peserta didik masih merupakan pembelajaran yang banyak hafalan dan membosankan dalam proses pembelajaran IPS guru juga tidak menggunakan pendekatan sehingga menyebabkan rendahnya prestasi belajar IPS peserta didik pada ujian asesmen semester I Tahun Ajaran 2019-2020, yaitu 60,71 masih di bawah Ketuntasan Belajar Minimal yaitu KKM pada pelajaran IPS adalah 75 yang mana dari 19 siswa yang tuntas 8 orang sedangkan tidak tuntas 12 orang. Dengan permasalahan tersebut penulis melakukan penelitian dengan menggunakan pendekatan Science Technology Community (STM). Adapun rumusan masalahnya adalah "Bagaimanakah peningkatan prestasi belajar IPS melalui pendekatan Ilmu Pengetahuan Teknologi Masyarakat (STM) di SDN 12 Parambahan"?

Tujuan penelitian ini adalah meningkatkan hasil belajar IPS siswa kelas V SDN 12 Parambahan, dan guru dapat merancang kesiapan belajar dengan pendekatan STM. Guru menggunakan pendekatan komunitas iptek dalam kegiatan belajar mengajar pada mata pelajaran IPS. A. Widowati (2011) menyatakan, "Pendekatan Sains Teknologi dan Masyarakat (STM) menjadikan teori kontruktivisme sebagai dasar. Pendekatan ini memberikan pemahaman tentang kaitan antara sains teknologi dan masyarakat, melatih kepekaan penilaian peserta didik terhadap dampak lingkungan sebagai akibat perkembangan sains dan teknologi. Pendekatan ini dapat merangsang pemahaman sains yang melatarbelakangi permasalahan, dan dampaknya bagi masyarakat. Siswa dapat menjadi sadar tentang berbagai motif dalam memutuskan suatu tindakan untuk mengatasi permasalahan lingkungan". STM mengartikann pembelajaran IPS itu adalah pembelajaran yang berkaitan dengan kehidupan siswa sebagai manusia sehari-hari sehingga perlu dikembangkan dalam pembelajaran. Menurut I Pt.Suwintara (2006) "Tujuan dari pendekatan STM ini adalah membentuk individu yang memiliki literasi sains dan teknologi." Disamping itu, individu juga akan memiliki kepedulian terhadap masalah masyarakat dan lingkungannya. Dengan adanya pengetahuan tentang sains, teknologi, dan lingkungan, maka siswa diharapkan mampu mengambil keputusan penting dan tindakan tentang masalah-masalah yang terjadi dalam masyarakat. Tujuan dari pendekatan STM menurut Y Miaz (2013) adalah "Mata pelajaran IPS lebih metnfok iskan perhatian kepada peran rnanusia dalam rnasyarakat. Di dalam proses pembelajaran diharapkan siswa akan rnanipu mengatasi permasalahan yang akan dihadapi dalam konstelasi global. yaiti untuk menjadi warga negara yang demokratis dan bertanggung jawab serta warga dunia yang cinta damai." Ilmu yang didapatkan dibangku sekolah bisa dimanfaatkan dan diterapkan di masyarakat yang dijembatani oleh Sains Teknologi Masyarakat.

Upaya mewujudkan pendidikan yang berkualitas dapat dilakukan dengan kerjasama antar elemen baik pemerintah, swasta, dan masyarakat. Pelibatan masyarakat tidak hanya dalam bentuk bantuan fisik (capital) tetapi juga berwujud modal sosial (capital social) (Yolanda Stepy, Firman Firman, 2020). Teori belajar yang digunakan untuk mendukung pendekatan STM adalah teori belajar kontruktivisme. Menurut NPEW Laksmi (2013) "Dengan menerapkan berbagai pendekatan yang inovatif seperti pendekatan STM untuk meningkatkan kualitas sikap ingin tahu, berdaya temu, berpikir kritis, ketekunan, dan keterbukaan ". Menurut S Silvinia (2010) langkah-langkah pendekatan STM sebagai berikut : 1) Invitasi, Guru dapat memberikan contoh berita fakta yang ada dimasyarakat kemudian diamati atau berita dari pendapat peserta didik yang sesuai dengan pelajarannya; 2) Observasi. Peserta didik memberikan aksinya serta menguasai, meninjau masalah baru bagi peserta didik tersebut. Peserta didik dapat menemukan dan mencari solusi dari masalah tersebut dengan cara membaca buku, diskusi, wawancara dan obsevasi langsung; 3) Penyelesaian riset. Peserta didik menganalisis terjadinya fenomena dan membahas bagaimana memecahkan masalah; 4) Tahap Aplikasi. Peserta didik berkesempatan menggunakan konsep-konsep yang telah diperoleh.

Dengan menggunakan langkah - langkah STM dalam pembelajaran IPS peserta didik mampu menganalisis yang mereka pelajari dengan yang ada di lingkungannya, peserta didik juga bisa melibatkan ilmu pengetahuan sebagai alat untuk menyelesaikan masalah sehari hari. Dalam proses pembelajaran yang diterima siswa dapat menerima dengan baik dan menangkap pelajaran yang diberikan dengan cepat, siswa juga banyak bertanya dan aktif dalam pembelajaran sehingga prestasi belajar siswa dapat ditingkatkan.

Sehingga dengan pendekatan STM prestasi belajar IPS siswa di SDN 12 Parambahan meningkat. Menurut OA Agusta (2014)" Nilai hasil belajar pada aspek observasi pendekatan STM lebih tinggi dibandingkan dengan pendekatan interaktif. Sedangkan kedua aspek yang lain yaitu aspek mengklasifikasi dan mengkomunikasikan dalam penerapanya pada kedua pendekatan hampir sama sehingga hasilnya belajarnya pun juga hampir sama". 


\section{Metode}

Penelitian ini dilaksanakan di kelas V SDN 12 Parambahan, Kecamatan Lima Kaum, Kabupaten Tanah Datar pada pembelajaran IPS semester II Tahun Pelajaran 2019/2020. Riset berlangsung tiga minggu dari tanggal 13 Januari-6 Februari 2020. Kelas V sebagai subjek riset. Subjek penelitian adalah 19 siswa, 9 laki-laki dan 10 perempuan. Menurut Slameto (2015) "Dalam implementasi PTK tahap merencanakan dan melakukan tindakan terdiri dari langkah utama yaitu: mengidentifikasi masalah, menganalisis dan merumuskan masalah, merencanakan tindakan kelas, melaksanakan tindakan kelas (membuat perencanaan, melaksanakan, observasi, analisis dan refleksi), mengumpulkan data dan menganalisis data tentang proses dan hasil beserta tindak-lanjutnya; terakhir adalah menulis laporan. Langkahlangkah ini merupakan langkah yang berurutan; artinya langkah pertama harus dikerjakan lebih dahulu sebelum langkah kedua dilaksanakan, demikian seterusnya".

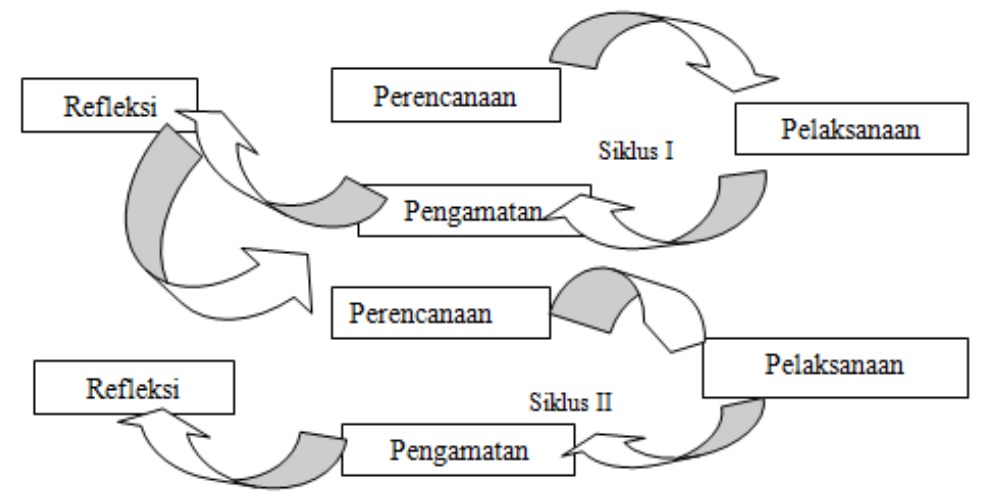

Instrumen riset yang peneliti gunakan adalah instrument telaah RPP dan instrument supervisi pembelajaran. Data dikumpulkan mengunakan eksplorasi, hasil supervisi, tanya jawab dengan guru serta angket. Jenis riset data kualitatif dan kuantitatif. Hasil nilai supervisi didapatkan dengan angka-angka yang akan dijadikann data kuantitatif dan catatan pribadi guru, observasi dan hasil wawancara dijadikan sebagai data kualitatif. Analisis data menggunakan pola yang dikemukakan F.Firman (2018), yakni perbedaan paradigma penelitian kuantitatif dengan kualitatif menyebabkan proses dan hasil penelitian kedua pendekatan tersebut berbeda.

\section{Hasil dan Pembahasan}

Pada siklus I pertemuan 1 hasil penilaian Perencanaan Pelaksanaan Pembelajara ( RPP) $78 \%$ dan pada pertemuan 2 dengan persentase $84 \%$. Pada siklus II penilaian RPP 88\%. Penilaian pelaksanaan proses pembelajaran siklus 1 pertemuan 1 dari aspek guru 75\%, pada pertemuan 2 persentase nilainya $82 \%$ dan pada siklus II 95\%. Untuk aspek siswa pada siklus I dengan nilai persentase $73 \%$ pertemuan kedua $84 \%$ dan siklus II 93\%. Hasil data di atas dapat dilihat pada grafik di bawah ini .

Grafik 1. Kenaikan persentase RPP, aspek Guru dan aspek Peserta didik dengan menggunakan pendekatan STM

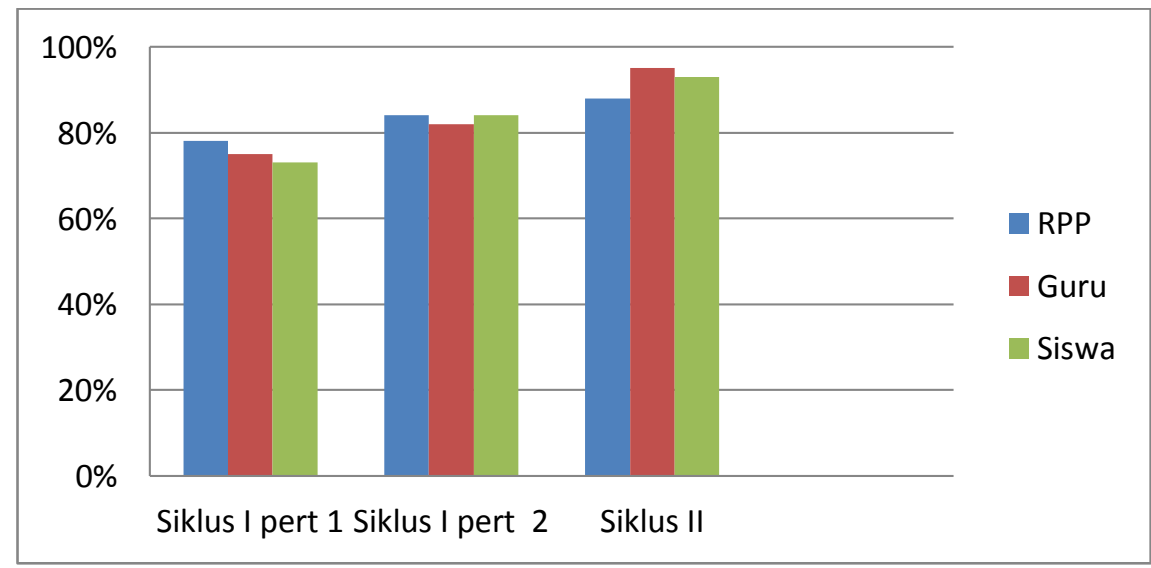


Dari grafik di atas terjadi peningkatan persentase keaktifan peserta didik dalam proses belajar IPS di kelas V SDN 12 Parambahan dengan penggunaan pendekatan STM, semua itu terlihat dari hasil instrumen guru, peserta didik dan RPP yang dibuat oleh guru untuk menjadi lebih baik dan meningkat dari tiap siklus.

Prestasi belajar IPS peserta didik dengan menggunakan pendekatan STM diketahui bahwa pada Siklus I pertemuan 1 rata-rata skor kognitif 61, afektif 68, psikomotor 69. Siklus 1 pertemuan 2 rata-rata kognitif 72 , afektifi 70 dan psikomotor 74. Pada siklus ke II nilai ratae - rata kognitif 83, afektif 82, psikomotor 79.Secara umum meningkat rata - rata prestasi belajar IPS peserta didik dari 60,71 (sebelum siklus) ke 69 (siklus ke-1), dan siklus ke- 2 memperoleh 80 . Uraian diatas bisa dilihat melalui grafik di bawah ini.

Grafik 2. Peningkatan prestasi belajar peserta didik dengan menggunakan pendekatan STM

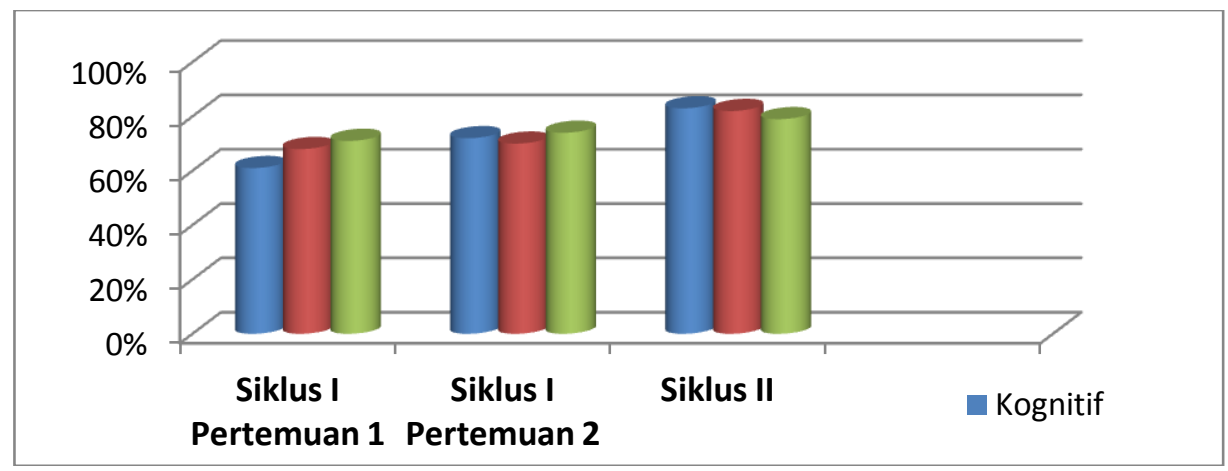

Hasil riset di atas dilakukan dengan 2 siklus, maka dapat dipahami bahwa peran guru dalam meningkatkann prestasi belajar IPS siswa kelas V SDN 12 Parambahan sangat penting dilakukan. Prestasi belajar IPS siswa dapat ditingkatkan dengan pendekatan STM di SDN 12 Parambahan.

Pada siklus pertama dapat dilihat rancangan RPP yang dibuat oleh guru dengan menggunakan pendekatan STM dengan persentase nilai 79\% kualifikasi baik. Pada siklus kedua ada peningkatan nilai $88 \%$ kualifikasi sangat baik.. Karena pada siklus kedua ini guru berusaha lebih maksimal.

Pelaksanaan pembelajaran IPS dengan menggunakan pendekatan STM juga mengalami penigkatan. Siklus I aktitas guru 79\% dengan kualifikasi baik, aktivitas peserta didik 77\% dikatergorikan baik. Siklus kedua ada peningkatan aktifitas guru persentase $95 \%$ dengan kualifikasi yang sangat bagus. Aktivisme peserta didik juga mengalami peningkatan penilaian sebesar 93\% dengan kualifikasi sangat baik.

Prestasi belajar IPS siswa dengan pendekatan STM pada siklus I tidak ada hasil yang memuaskan, Prestasi belajar IPS siswa masih kurang dengan capaian inndikator rata-rata menunjukkan 69. Pada siklus II siklus rata-rata nilai belajar IPS siswa meningkat. ke 80. Oemar (1997) menyatakan "Hasil belajar adalah perilaku yang muncul, misalnya dari tidak tahu menjadi tahu, pertanyaan baru yang muncul, perubahan tahapan kebiasaan, keterampilan, kemampuan menghargai perkembangan karakteristik sosial, perubahan emosi dan perubahan fisik". Hasil penelitian di atas sesuai dengan pendapat Aderusliana (2007) "dengan range nilai, 80100 kategori sangat baik, 70-79 kategori baik, 60-69 kategori sedang dan - 59 kategori buruk".

Keberhasilan suatu pendidikan tidak hanya diukur dari pencapaian kognitif, tetapi yang lebih penting juga dilihat dari segi afektif dan perilaku. Saling menghormati dan menghormati dalam interaksi sosial baik di sekolah maupun di luar sekolah perlu mendapat perhatian. Oleh karena itu, keterampilan sosial sangat perlu diajarkan di sekolah. Keterampilan sosial meliputi tujuan utama pendidikan untuk meningkatkan kesiapan sekolah seperti kemampuan menghargai orang lain, bekerja sama secara kooperatif, mengekspresikan emosi dan perasaan dengan cara yang baik, mendengarkan orang lain, mengikuti aturan dan prosedur, duduk dengan penuh perhatian, dan untuk bekerja secara mandiri.

Dalam pembelajaran IPS dengan model pembelajaran STM, siswa dilibatkan dalam penerapan konsep IPS dalam kehidupan sehari-hari. Penerapan konsep IPS ada pada teknologi, sehingga siswa mengenal teknologi yang ada di sekitarnya. Kemudian dari observasi ke lingkungan, siswa menemukan kesimpulan atau konsep IPS sendiri. Guru hanya membimbing siswa dalam memperoleh konsep yang dimaksudkan. Dengan demikian, pembelajaran IPS dengan model pembelajaran STM akan mampu memaksimalkan keterampilan sosial peserta didik, dan meningkatkan sikap literasi terhadap IPTEK.

Dari pembahasan diatas dapat dilihat bahwa menggunakan pendekatan STM pada rancangan RPP yang dibuat oleh guru, proses pelaksanaan pembelajaran IPS yang berlangsung dan prestasi belajar IPS peserta didik yang menggunakan pendekatan STM dapat meningkat kan prestasi belajar IPS peserta didik, 
dibandingkan sebelum menggunakan pendekatan STM. Hal diatas dapat terjadi karena STM mempunyai keunggulan - keunggulan tertentu. Menurut P Rintayati (2014) "Pembelajaran dengan pendekatan Sains Teknologi Masyarakat dapat membuat siswa memiliki keberanian dalam menyampaikan pendapatnya, dan aktivitas yang baik dalam proses pembelajaran. Pada akhirnya, hasil belajar IPS siswa menjadi lebih baik pula".

\section{Simpulan}

Pendekatan STM efektif digunakan untuk meningkatkan prestasi belajar siswa sehingga dengan penggunaan pendekatan STM pada mata pelajaran IPS prestasi belajar IPS siswa kelas V SDN 12 Parambahan Kecamatan Lima Kaum Kabupaten Tanah Datar meningkat. Hal ini terlihat dari peningkatan hasil belajar IPS siswa dari siklus I dengan rata-rata 69 menjadi 80 pada siklus II. Dan keaktifan siswa juga meningkat dari siklus I 77\% ke siklus II 93\% karena dengan menggunakan pendekatan STM, kondisi belajar yang lebih aktif dan variatif dapat tercipta dengan mengembangkan rasa peduli terhadap perkembangan ilmu pengetahuan dan teknologi. Dengan menggunakan pendekatan STM, mahasiswa membangun pengetahuannya sendiri, menemukan langkah-langkah dalam mencari penyelesaian masalah yang terjadi terkait dengan teknologi. Bagi guru diharapkan menjadikan pendekatan STM sebagai suatu alternative untuk memberikan pelajaran IPS dan mata pelajaran lainnya.

\section{Referensi}

Jauhar, S. (2018). Pengembangan Bahan Ajar Ips Berbasis Pendekatan Sains Teknologi Masyarakat (Stm) Untuk Meningkatkan Kreativitas Siswa Di Sekolah Dasar. JIKAP PGSD: Jurnal Ilmiah Ilmu Kependidikan, 2(2), 58. https://doi.org/10.26858/jkp.v2i2.6946

Ni P. E. Wahyu Laksmi, D. P. P. N. K. (2013). Pengaruh Pendekatan Sains Teknologi Masyarakat Bermuatan Kearifan Lokal Tri Hita Karana Terhadap Sikap Ilmiah Siswa Kelas Iv Sd Negeri 1 Ubud. MIMBAR PGSD Undiksha, 1(1). https://ejournal.undiksha.ac.id/index.php/JJPGSD/article/view/681

Pgsd, J. (n.d.). Sd Gugus V Kecamatan Sawan.

Rintayati, P., \& Putro, P. (2012). Meningkatkan Aktivitas Belajar (Active Learning) Siswa Berkarakter Cerdas dengan Pendekatan Sains Teknologi (STM). Jurnal Didaktika Dwija Indria, 1(2), 1-24. http://jurnal.fkip.uns.ac.id/index.php/pgsdsolo/article/download/82/54

Saharuddin, M. (2020). STRATEGI PEMBELAJARAN IPS : Konsep dan Aplikasi.

Sapti, M. (2019). Kemampuan Koneksi Matematis (Tinjauan Terhadap Pendekatan Pembelajaran Savi), 53(9), 16891699.

Slameto, S. (2015). Implementasi Penelitian Tindakan Kelas. Scholaria: Jurnal Pendidikan Dan Kebudayaan, 5(3), 47. https://doi.org/10.24246/j.scholaria.2015.v5.i3.p47-58

Stepy, Y., \& Firman, F. (2020). Modal sosial paguyuban dalam pengembangan fasilitas pendidikan di sekolah dasar. JPGI (Jurnal Penelitian Guru Indonesia), 5(1), 1. https://doi.org/10.29210/02503jpgi0005

Widowati, A. (2011). Membentuk Generasi Berliterasi Lingkungan dengan Penerapan Pendekatan STM dalam Pembelajaran Sains. Seminar Nasional Pendidikan IPA, 407-414. 